\title{
Effect of Water Vapor on the Solid-State Reaction between Hydroxyapatite and Zirconia or CaO-PSZ
}

\author{
Kimihiro YAMASHITA, Takashi KOBAYASHI, Masako KITAMURA, \\ Takao UMEGAKI and Takafumi KANAZAWA \\ (Department of Industrial Chemistry, Faculty of Technology, Tokyo Metropolitan University, \\ 1-1, Fukasawa 2-chome, Setagaya-ku, Tokyo 158
}

\author{
山下仁大・小林 高・北村正子・梅垣高士・金澤孝文 \\ (東京都立大学工学部工業化学科, 158 東京都世田谷区深沢 2-1-1)
}

ハイドロオキシアパタイトとジルコニア又は CaO-PSZ 間の固相反応に及ぼす水蒸気の影響

\begin{abstract}
A dense composite of hydroxyapatite (HAP)-PSZ was obtained without decomposition of HAp to tri-calcium phosphate (TCP). The condition necessary for the sintering was a supply of water vapor stream to the atmosphere. It was also clarified that the solid-state reaction between $\mathrm{HAp}$ and $\mathrm{ZrO}_{2}$ does not necessarily cause decomposition of the apatitic structure. Considering the thermal stability of partially dehydrated oxyhydroxyapatite, the effect of water vapor on the solid-state reaction between HAp and PSZ was discussed in relation to the decomposition of the apatitic structure in HAp-PSZ composites.
\end{abstract}

[Received September 1, 1987 ; Accepted March 24, 1988]

Key-words: Hydroxyapatite, PSZ, Zirconia, Water vapor effect

\section{Introduction}

Partially stabilized zirconia (PSZ) has been recently found an effective additive in toughening and strengthening hydroxyapatite $\left(\mathrm{Ca}_{10}\left(\mathrm{PO}_{4}\right)_{6}\right.$ $\left.(\mathrm{OH})_{2}: \mathrm{HAp}\right)^{11}$ ceramics. However, it has also been reported that the apatitic structure decomposes to tri-calcium phosphate $\left(\mathrm{Ca}_{3}\left(\mathrm{PO}_{4}\right)_{2}\right.$ : TCP) in the solid-state reaction of $\mathrm{HAp}$ and $\mathrm{ZrO}_{2}{ }^{2)-4)}$ or $\mathrm{Y}_{2} \mathrm{O}_{3}-\mathrm{PSZ}{ }^{11-3)}$

The primary aim of the present work is to produce dense HAp-PSZ composites without decomposition of the apatitic structure. According to some reports, ${ }^{1,4)}$ the decomposition can be expressed with the reactions;

$$
\mathrm{HAp} \rightarrow 3 \mathrm{TCP}+\mathrm{CaO}+\mathrm{H}_{2} \mathrm{O}(\mathrm{g}),
$$

and $\mathrm{CaO}$ (from $\mathrm{HAp}$ ) $+\mathrm{ZrO}_{2} \rightarrow \mathrm{PSZ} \rightarrow \mathrm{CaZrO}_{3}$

$$
\text { (2) }
$$

When these reactions are considered, the following two factors may be expected to have some influences on the decomposition; ( $i$ ) the water vapor in the sintering atmosphere and (ii) the concentration of $\mathrm{CaO}$-stabilizer of PSZ. In order to investigate their effects, sintering behavior of various $\mathrm{HAp}-\mathrm{PSZ}$ composites under water vapor stream and in the air was studied in the present work. For comparison, the sintering of $\mathrm{HAp}-8$ mol\% $\mathrm{Y}_{2} \mathrm{O}_{3}$-stabilized $\mathrm{ZrO}_{2}$ and $\mathrm{HAp}-\mathrm{Al}_{2} \mathrm{O}_{3}$ composites were also studied.

\section{Experimental procedure}

Precursor powders of HAp were synthesized by the coprecipitation method ${ }^{5)}$ from aqueous solutions of analytical-grade $\mathrm{Ca}\left(\mathrm{NO}_{3}\right)_{2} \cdot 4 \mathrm{H}_{2} \mathrm{O}$ and $\left(\mathrm{NH}_{4}\right)_{2} \mathrm{HPO}_{4}$. Starting $\mathrm{HAp}$ powders were obtained by calcining the freeze-dried precipitates.

Various kinds of partially $\mathrm{CaO}$-stabilized $\mathrm{ZrO}_{2}$ powders were prepared by the thermal treatment of $\mathrm{ZrO}_{2}{ }^{*}$ mixed with $\mathrm{CaCO}_{3}$ at $1300^{\circ} \mathrm{C}$. The addition of $\mathrm{CaO}$ was in the range of 0 to $13 \mathrm{~mol} \%$ of $\mathrm{ZrO}_{2}$. A specimen of PSZ added with $x$ mol\% $\mathrm{CaO}$ is referred to hereafter as $\operatorname{PSZ}(x \mathrm{C})(x=$ $3,7,10,13)$, while undoped $\mathrm{ZrO}_{2}$ is labelled as $Z$ $(0 \mathrm{C})$. In the study of the system $\mathrm{Y}_{2} \mathrm{O}_{3}$-stabilized $\mathrm{ZrO}_{2}$-and $\mathrm{Al}_{2} \mathrm{O}_{3}$ - $\mathrm{HAp}$, commercial products of $\mathrm{Al}_{2} \mathrm{O}_{3}$ and $8 \mathrm{~mol} \% \mathrm{Y}_{2} \mathrm{O}_{3}$-stabilized $\mathrm{ZrO}_{2}\left(\mathrm{TZ}-8 \mathrm{Y}^{*}\right)$ were employed. According to the manner of PSZ $(x \mathrm{C})$ notation, the latter will be referred to as PSZ(16Y).

Specimens studied in the present work were HAp added with 10 wt $\% \operatorname{PSZ}(x \mathrm{C}), \operatorname{PSZ}(16 \mathrm{Y})$ or $\mathrm{Al}_{2} \mathrm{O}_{3}$. HAp was mixed with those oxides in a plastic ball-milling bottle for a day. The mixed powders were pressed into pellets with a thickness of $1 \mathrm{~mm}$ and a diameter of $10 \mathrm{~mm}$. Sintering was carried out at $1200^{\circ}$ to $1400^{\circ} \mathrm{C}$ for several hours in

* TZ and TZ-8Y(Toso Co., Ltd. ) 
the atmosphere of air or $\mathrm{H}_{2} \mathrm{O}$ vapor. Sintered bodies were cooled in a furnace. Relative density of a sinter was measured in butanol by the picnometric method. A specimen of HAp mixed with $\operatorname{PSZ}(x \mathrm{C})$ additive is designated hereafter as HAp-PSZ $(x \mathrm{C})$.

Sintered pellets and their crushed powders were employed in the X-ray diffraction (XRD) studies for phase analysis. For semiquantitative study on the change of the concentrations of the phases TCP and PSZ present in a composite, the indices, $f_{\mathrm{TCP}}$ and $f_{\mathrm{PSZ}}$, were introduced, where $f_{\text {TCP }}$ and $f_{\text {PSz }}$ correspond to, respectively, the quantity of HAp decomposing to TCP and that of PSZ increased during sintering. The former index is calculated as $f_{\mathrm{TCP}}=I_{\mathrm{TCP}(034)} /\left(I_{\mathrm{HAP}(211)}+\right.$ $\left.I_{\mathrm{TCP}(034)}\right)$, where $I_{\mathrm{TCP}(034)}$ and $I_{\mathrm{HAP}(211)}$ are respectively the XRD intensities of ( $\left.\begin{array}{llll}0 & 3 & 4\end{array}\right)$ of TCP and (2 111 ) of HAp phases. The latter index, on the other hand, is calculated as $f_{\mathrm{PSZ}}=\left[I_{c-\mathrm{PSZ}} / I_{\mathrm{HAP}(211)}\right]$, which is the value obtained by extracting $I_{c-\mathrm{PSZ}} / I_{\mathrm{HAP}(211)}$ of a green powder from that of a crushed sinter, where $I_{c-\mathrm{Psz}}$ is the XRD intensity of (111) of cubic phase. $f_{\mathrm{PSz}}$ is calculated from the data of the cubic phase PSZ. The monoclinic phase of the sinter was too weak to be detected.

Lattice parameters of HAp and cubic PSZ phases present in a sinter were calculated in order to follow the change of solid-state reactions between HAp and zirconia. Refractive indices employed for the calculation were respectively as follows: about 20 peaks between 25 and 50 degrees as $2 \theta$ for HAp, and peaks of (111) and (200) for c-PSZ, respectively.

\section{Results}

Figure 1 shows the simplified XRD patterns of $\mathrm{HAp}-\mathrm{PSZ}(10 \mathrm{C})$ and $-\mathrm{Al}_{2} \mathrm{O}_{3}$ composites which were sintered in the air or under water vapor stream. It can be seen from the figures that the apatitic phase of $\mathrm{HAp}-\mathrm{PSZ}(10 \mathrm{C})$ and $-\mathrm{Al}_{2} \mathrm{O}_{3}$ completely decomposed to TCP while being sintered in the air. For all of the HAp-PSZ $(x \mathrm{C})$ composites sintered in the air, decomposition of the HAp phase was observed. On the other hand, in HAp-PSZ (10C), the apatitic phase was almost wholly retained in a wet atmosphere even at $1400^{\circ} \mathrm{C}$. In $\mathrm{HAp}-\mathrm{Z}(0 \mathrm{C})$, a small amount of TCP was found even under a water vapor stream, although the HAp phase was considerably decomposed to TCP while being sintered in the air. Therefore, by supplying water vapor to the sintering atmosphere, the decomposition of HAp to TCP was found to be effectively suppressed. Similar results were obtained in HAp-PSZ $(16 \mathrm{Y}){ }^{2), 3)}$

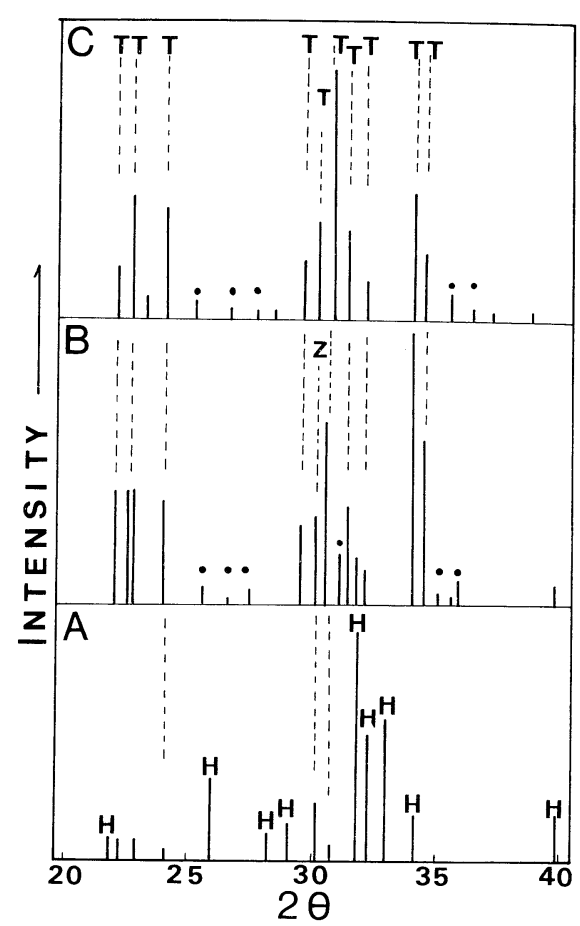

Fig. 1. X-ray diffraction patterns of the conposites HAp-PSZ (10C) (in wet atmosphere, A and in air, B) and $\mathrm{HAp}-\mathrm{Al}_{2} \mathrm{O}_{3}$ (in air, $\mathrm{C}$ ). The alphabets in the figure indicate the phases as; T: $\alpha$-TCP, H : HAp and $Z$ : cubic-PSZ, respectively. Solid circles can be assigned to $\beta$-TCP.

Table 1. Effect of water vapor on concentration ratios of the phases tri-calcium phosphate and cubic zirconia to hydroxyapatite of sintered bodies.

\begin{tabular}{|c|c|c|}
\hline & $f_{\text {PSZ }}$ & $f_{\text {TCP }}$ \\
\hline \multirow{4}{*}{$\frac{2}{0}$} & 0.01 & 0.22 \\
\hline & 0.12 & 0.62 \\
\hline & 0.31 & 0.43 \\
\hline & 0.36 & 0.57 \\
\hline \multirow{4}{*}{$\stackrel{+}{3}$} & 0.15 & 0 \\
\hline & 0.17 & 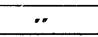 \\
\hline & 0.22 & ". \\
\hline & 0.26 & 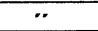 \\
\hline
\end{tabular}

Table 2. Densities of HAp-PSZ $(x \mathrm{C})$ composites under various sintering conditions in water vapor.

\begin{tabular}{|c|cc|c|}
\hline Additive & \multicolumn{2}{|c|}{$\begin{array}{c}\text { Sintering } \\
\text { Temp. }\left({ }^{\circ} \mathrm{C}\right),\end{array}$} & $\begin{array}{c}\text { Density }(\mathrm{h}) \\
\mathrm{g} / \mathrm{cm}^{3}\end{array}$ \\
\hline None & 1400 & 4 & 3.12 \\
Z(OC) & 1300 & 4 & 3.32 \\
PSZ(3C) & 1300 & 4 & 3.26 \\
PSZ(7C) & 1300 & 1 & 3.27 \\
PSZ(10C) & 1300 & 4 & 3.26 \\
PSZ(13C) & 1300 & 1 & 3.27 \\
\hline
\end{tabular}




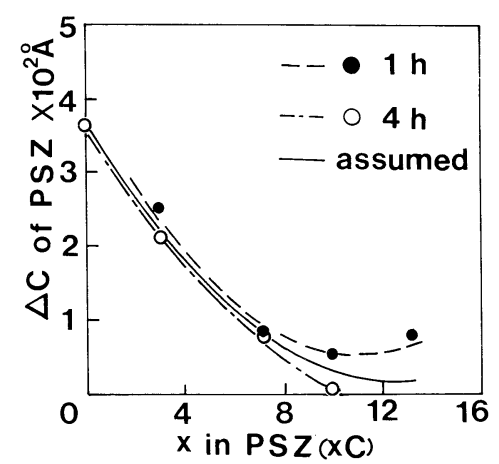

Fig. 2. Effect of $\mathrm{CaO}$ content in $\mathrm{PSZ}$ on the change in the lattice parameter of cubic-PSZ during sintering $\left(\Delta c\right.$ of PSZ). Specimens were sintered at $1300^{\circ}$ and $1400^{\circ} \mathrm{C}$ for $1 \mathrm{~h}$ or $4 \mathrm{~h}$. The solid line was drawn to indicate the average relationship assumed for the parameters.

Table 1 summarizes the values of the indices $f_{\text {TCP }}$ and $f_{\text {PSz }}$. As can be seen, $f_{\text {TCP }}$ increased with an increase of $f_{\mathrm{Psz}}$ while being sintered in the air. On the other hand, in the sintering under a water vapor stream, despite $f_{\mathrm{PSZ}}>>0$, the $f_{\text {TCP }}$ was almost zero, indicating no decomposition of HAp.

Listed in Table 2 are the relative densities of $\mathrm{HAp}-\mathrm{Z}(0 \mathrm{C})$ and $-\mathrm{PSZ}(x \mathrm{C})$ sintered at $1300^{\circ}$ to $1400^{\circ} \mathrm{C}$ for $1 \mathrm{~h}$ or $4 \mathrm{~h}$ under a water vapor stream. For sintered HAp, the value of $3.13\left(\mathrm{~g} / \mathrm{cm}^{3}\right), c a$. $98 \%$ of the theoretical density, was obtained. Such high density $\left(>3.2\left(\mathrm{~g} / \mathrm{cm}^{3}\right)\right)$ was attained in all of the specimens. Although HAp-Z(OC) exhibited the highest value of $3.33\left(\mathrm{~g} / \mathrm{cm}^{3}\right)$, scarcely any distinctive difference was found in density among various $\mathrm{HAp}-\mathrm{PSZ}(x \mathrm{C})$ sinters. Thus, dense sinters of HAp-PSZ composites with little TCP phase were successfully obtained.

Figure 2 shows how the lattice parameter of the cubic phase $\operatorname{PSZ}(x \mathrm{C})$ changed with the concentration of $\mathrm{CaO}$-stabilizer, i.e. the value of $x$, while being sintered under a water vapor stream $\left(f_{\mathrm{TCP}}=0\right)$. The figure indicates that the unit cell volume changed less in a PSZ $(x \mathrm{C})$ precedingly added with more $\mathrm{CaO}$ stabilizer; i. e., more $\mathrm{Ca}^{2+}$ (or $\mathrm{CaO}$ ) was transported from HAp to PSZ added precedingly with less $\mathrm{CaO}$-stablizer.

\section{Discussion}

A close study of the Eqs. (1) and ( 2 ) will be helpful for the understanding of the effect of water vapor on the solid-state reactions between HAp and PSZ. As Eq. (1) expresses the complete decomposition of HAp, the partial decomposition Eq. ( $\left.1^{\prime}\right)$ is considered in place of Eq. ( 1 ) for the discussion below.

$$
\begin{aligned}
& \mathrm{HAp} \rightarrow\left[\mathrm{Ca}_{10-x} \square_{x}\right]\left(\mathrm{PO}_{4}\right)_{6}\left[(\mathrm{OH})_{2-2 x} \square_{2 x}\right] \\
& \quad+x \mathrm{CaO}+x \mathrm{H}_{2} \mathrm{O}(\mathrm{g}),
\end{aligned}
$$

where the notation $\square$ expresses a vacancy. $\left[\mathrm{Ca}_{10-x} \square_{x}\right]\left(\mathrm{PO}_{4}\right)_{6}\left[(\mathrm{OH})_{2-x} \square_{2 x}\right]$ is the partially decomposed hydroxyapatite and denoted as $p d$ HAp.

The fact that undoped HAp was stable after the sintering at $c a .1300^{\circ} \mathrm{C}$ even in the air indicates that HAp does not voluntarily decomposes to TCP. Additionally, from the result that HAp underwent the decomposition as $\mathrm{CaO}$ was transported from HAp to PSZ, the reaction written by Eq. ( 2 ) must have occurred in the beginning and have initiated the reaction of Eq. ( 1 ). However, as evidenced above, despite the occurrence of $\mathrm{CaO}$-diffusion from HAp to $\mathrm{PSZ}$, the apatitic structure was maintained under water vapor stream.

To explain those results, the consideration of the stability of partially dehydrated oxyhydroxyapatite ( $p d-\mathrm{OHAp})$, which has the apatitic structure, might be useful. pd-OHAp is obtained according to the following;

$$
\begin{aligned}
& \mathrm{HAp} \rightarrow \mathrm{Ca}_{10}\left(\mathrm{PO}_{4}\right)_{6} \\
& \quad\left[(\mathrm{OH})_{2-2 x} \mathrm{O}_{x} \square_{x}\right]+x \mathrm{H}_{2} \mathrm{O}(\mathrm{g}) .
\end{aligned}
$$

Its apatitic structure can be retained in reducing atmosphere ${ }^{6)}$ at lower temperatures up to $900^{\circ} \mathrm{C}$, while it is unstable at higher temperatures. Even below $900^{\circ} \mathrm{C}$, it undergoes the decomposition under vacuum. ${ }^{7)}$ These facts suggest that whether the apatitic structure is retained depends on the degree of dehydration, i.e., the value of $x$ in Eq. (3). In other words, in the occurrence of a considerable amount of $\mathrm{OH}^{-}$vacancies, the apatitic structure will be retained no longer.

By analogy with the stability of $p d-\mathrm{OHAp}$, it was deduced that the degree of $\mathrm{Ca}^{2+}$-deficiency of $p d$-HAp (the value of $x$ in Eq. $\left(1^{\prime}\right)$ ) may determine whether the apatitic structure of a HAp-PSZ composite can be retained or decomposed. Concerning the HAp-decomposition of HAp-PSZ composites, it may be said that the amount of $\mathrm{Ca}^{2+}$ and $\mathrm{OH}^{-}$vacancies produced by the reaction between $\mathrm{HAp}$ and $\mathrm{ZrO}_{2}$ will determine the stability of the apatitic structure.

In the sintering in the air, the $\mathrm{CaO}$-diffusion from $\mathrm{HAp}$ to $\mathrm{ZrO}_{2}$ would continue to produce $\mathrm{Ca}^{2+}$ -vacancies of $p d$-HAp and undergo the decomposition according to Eqs. $\left(1^{\prime}\right)$ and (2). On the other hand, in the sintering under water vapor stream, the one-way diffusion can be hardly thought to be exclusive because of the retention of the apatitic structure. Alternatively, an interdiffusion (Eq. (4)) of $\mathrm{Ca}^{2+}$ and $\mathrm{Zr}^{2+}$ with or without $\mathrm{O}^{2-}$ was assumed in the present study; $\mathrm{Ca}^{2+}($ from $\mathrm{HAp})+\mathrm{ZrO}_{2} \rightarrow \mathrm{PSZ} \rightarrow \mathrm{CaZrO}_{3}$ 
and $\mathrm{Zr}^{4+}\left(\right.$ from $\left.\mathrm{ZrO}_{2}\right)+\mathrm{HAp}$

$\rightarrow$ zirconia incorporated HAp.

The direct effect of water vapor can be attributed to suppression of the evaporation of $\mathrm{H}_{2} \mathrm{O}$ in Eq. $\left(1^{\prime}\right)$, and the interdiffusion can occur only in the presence of much water vapor in the atmosphere.

By analogy with trivalent-cation-substituted calcium oxyhydroxyapatite, this type of zirconia incorporated $\mathrm{HAp}$ may be compositionally written as $\mathrm{Ca}_{10-w} \mathrm{Zr}_{w}\left(\mathrm{PO}_{4}\right)_{6}\left[(\mathrm{OH})_{2-2 w} \mathrm{O}_{2 w}\right]$.

Further study is under investigation.

Acknowledgments This work was partly supported by a Grand-in-Aid for Scientific Research (No. 61430018) from the Ministry of Education, Culture and Science of Japan, and by the Nippon Sheet Glass Foundation for Research and Development on Materials Technology. The authors are also greatly thankful to Mr. H. Suzuki of Toso Co., Ltd. for his supplying zirconia ( $\mathrm{TZ}$ and $\mathrm{TZ}-8 \mathrm{Y}$ ).

\section{References}

1) N. Tamari, M. Mouri and I. Kondo, Yogyo-Kyokai-Shi, 95, 806-09 (1987).

2) K. Yamashita, M. Kitamura, A. Tanabe, T. Umegaki and T. Kanazawa, Proc. the 5th Symposium on Inorganic Phosporus Chemistry (1985) p. 78.

3) K. Yamashita, T. Umegaki and T. Kanazawa, Proc. the 72 th Meeting of the Institute of Gypsum \& Lime Research (1986) p. 15.

4) N. Miura, M. Akao, H. Aoki and K. Kato, Rep. Inst. Med. Dentl. Engr., 17, 21-27 (1983).

5) K. Yamashita, H. Owada, H. Nakagawa, T. Umegaki, and T. Kanazawa, J. Am. Ceram. Soc., 69, 590-94 (1986).

6) J. C. Trombe and G. Montel, J. Inorg. Nucl. Chem., 40, 15-21 (1978).

7) J. C. Trombe and G. Montel, J. Inorg. Nucl. Chem., 40, 23-26 (1978). 